Derleme Makale • Review Article

\author{
Byung-Chul Han'da “Absürt Olanı İsteyen” Özne: \\ "Yeni Budala” Tiplemesi Üzerine Sosyolojik Bir Çözümleme
}

\author{
The Subject "Wanting The Absurd" in Byung-Chul Han: A Sociological Analysis on The \\ "New Silly" Typecasting
}

Rukiye GEÇER ${ }^{*}$

0000-0001-7149-7606

\section{MAKALE BİLGISİ}

Başvuru: 30.08.2021

Düzeltme Talebi: 07.10.2021

Son Düzeltme: 23.10 .2021

Kabul: 07.12.2021

Online Yayım: 15.12.2021

\section{Anahtar Kelimeler:}

\section{Sosyoloji}

Yeni İnsan

Özne

Tüketim

Yeni Budala

\section{ÖZ}

Sosyoloji literatüründe sözü geçen "yeni insan" tanımlamasını anlama isteği, bu makalenin hikâyesini temsil eder. Tanımlamanın bağlamına yönelik geniş muhteva göz önünde bulundurulursa, bir sınırlandırma yapma zorunluluğu hâsıl olur. Bu sınırlandırmanın Byung-Chul Han tarafından öne sürülen "yeni budala" tiplemesi üzerinden yapılması çalıșma için önem arz eder. "Yeni budala" derken neyin kastedildiği, kimlerin bu tipleștirmenin sınırlarına dâhil olduğu söz konusu olduğunda tüketim kavramı karșımıza çıkar. İsteklerin tatminine yönelik bir olgu olarak ele alınan tüketimin bireyin günlük yaşamını hangi ölçülerde etkilediği, nerelere kadar sindiği göz önünde bulundurularak, tüketim öznesinin aktörel varlığı çalıșmanın gelișme așamasını olușturur. $\mathrm{Bu}$ bağlamda; yeni insanı temsil eden, -Byung-Chul Han tarafından da öne sürülen- başarı ve performansa odaklı geç modern özne, tipleştirmenin muhayyel yapısını şekillendirecektir. Tüketim öznesinin "isteyen" bir varlık olması, bu istemeyi "absürt olan" üzerinden gerçekleştirmesi makalenin yönettiği insanın hangi insan olduğu konusunda ipucu verir. Hassaten "isteyen" bir varlık olan tüketim öznesine değer atfetmemizi sağlayan eylemler ve bu eylemleri yöneten gücün "absürt olanı isteyen yeni budala" için nasıl bir anlam ihtiva ettiği söz konusu ipucunu açmamı için önemlidir. Bu anlamda tüketim, insan ve özne ilişkisinin pratiklere yansıyan boyutunu anlayabilmek adına; eylem ve iktidar kavramlarına ayrıca yer verilmiştir. Sonuç olarak bu makalenin hedefi; tüketici olmanın derin anlamlarına bir de Byung-Chul Han'ın kavramları ile bakmak șeklinde düşünülmelidir.

\section{A B S T RACT}

The desire to understand the definition of "new human" in the sociological literature represents the story of this article. Considering the broad context of the definition, it becomes necessary to make a limitation. It is important for the study to make this limitation based on the "new silly" typecasting put forward by Byung-Chul Han. When it comes to what is meant by the "new silly" and who is included in the limits of this typification, the concept of consumption comes up. Considering the extent to which consumption, which is considered as a phenomenon for the satisfaction of desires, affects the daily life of the individual and how far it is absorbed, the actorly existence of the subject of consumption constitutes the development stage of the study. In this context, the late modern subject, which represents the new human and is focused on success and performance, as suggested by Byung-Chul Han, will shape the imagined structure of typification. The fact that the subject of consumption is a being "who wants", and that they realize this will be realized through which is "the absurd" gives a clue as to which person is the person directed by the article. It is important for us to open the aforementioned clue as to the actions that enable us to attribute value to the subject of consumption, specifically an entity "who wants", and what the power that governs these actions means for the "new silly who wants the absurd". In this sense, in order to understand the dimension of consumption, human, and subject relationship reflected in practices, the concepts of action and power are also included. In conclusion, the aim of this article is that it should be considered as looking at the deep meanings of being a consumer with Byung-Chul Han's concepts.

\footnotetext{
* 1 Yazar İletişim / Corresponding Author: Rukiye Geçer (Arş. Gör.), Samsun Üniversitesi, İktisadi, İdari ve Sosyal Bilimler Fakültesi, Sosyoloji, Samsun, Türkiye $₫$ rukiye.gecer@samsun.edu.tr

Kaynak Gösterimi/ Citing This Article: Geçer, R. (2021). Byung-Chul Han'da “Absürt Olanı İsteyen” Özne: "Yeni Budala” Tiplemesi Üzerine Sosyolojik
} Bir Çözümleme. Sosyolojik Bağlam Dergisi, 2(3), 87-98. doi: 10.52108/2757-5942.2.3.6 


\section{Giriș \\ “...eski budala kendinden çıkarak varacağı apaçıklıklar peşindeydi, bu esnada da her şeyden şüphe ediyordu. Yeni budalaysa hiçbir apaçıklık istemiyor. Absürt olanı istiyor."}

Byung-Chul Han

Duygu, düşünce ve inançlar etrafinda maddi bir varlık kazanan pratikler, insana bir eyleme "değer atfeden" olarak yaklaşılması gerektiğini gösterir. Pratiklere belirli bir sabite kazandıran eylemlerin varlığı, aktif bir öznenin varlığı ile mümkün olur. Bu izlekte makaledeki tipleștirmeyi yönetecek olan özne, biraz da risk toplumunun, bilgi toplumunun, hız toplumunun, ağ toplumunun; daha genel anlamda post-modern sürecin bir parçası olan insanın aktif bir katılımcı olduğu öznedir. Bu öznenin arka planını, tüketim olgusu oluşturur. Eylemlerin arka planında daima varlığını sürdüren tüketim olgusu, bir yerde insanın aktif bir özne olma hikâyesinin bir parçasıdır. Arzu eden, tatmin arayan insanın; aradıkça yitiren, yitirdikçe kendine yönelen, kendini kendinde arayan, kendini kendinde gözeten, kendini kendiyle sömüren bir özneye yönelme arzusu onun hikâyesinde tüketme ve tükenme eylemini vazgeçilmez kllar.

Pratikler şeklinde zikredilerek rutinleştiği kabul edilen bu eylemleri etkileyen ve bu eylemlerden beslenen kültürel oluşumlardan hareketle özneye sinen bu kalıplar, makalenin "neoliberal varlığa" özel bir önem atfetmesini sağlamıştır. Neoliberal varlığın, söz konusu özellikleri taşıyan, bu özelliklerden beslenen ve bu özelliklerin görünürlük kazanmasına aracı olan öznenin anlaşılması noktasında belirginleşmesi, bu özel önemin sebebini açıklamak için yeterlidir. Bu bağlamda onun eylediği en önemli iş, tüketme eylemidir. Bu yönüyle neoliberal varlığın öznesi, tüketen insandır. Tükettikçe tüketilen, tüketildikçe tüketen, sömürdükçe sömürülen, sömürüldükçe sömüren aktif bir öznedir.

Anlatılanlara atfen, tüketim politikasının psikolojik tahakküm tekniği, insanın psikopolitik olan yanına vurgu yapacaktır. İnsanın neoliberal rejimin psikopolitik tahakküm tekniklerine kendi rızası ile razı olması ise Byung-Chul Han'ın başarıya ve performansa odaklı öznesine yönelik değerlendirmelerin referanslığı ile açıklanacaktır. Bu yüzden makalenin görünen şeklini almasında Psikopolitika'nın yanında Şiddetin Topolojisi'nin de önemli bir yeri olacaktır. Söz konusu eserlerden hareketle, Han'ın "yeni budala" olarak nitelendirdiği tipleştirmenin hangi özelliklere haiz olduğu, tipleştirmenin öznesinin nitelikleriyle bir arada okunarak anlamlandırılmaya çalışılacaktır. Haddi zatında, tüketimin günlük yaşamdaki eylemlere çok yönlü etkisine yönelik tartışmaların ve kavramsallaştırmaların bir araya getirilmesi, bu kavramsallaştırılmayla birlikte söz konusu iki eserin derinlemesine tartışılması, böylelikle tüketme ve tükenme; daha genel anlamda tüketici olmanın derin anlamlarına inmeye yönelik bir bakış açısı yakalanması makalenin yazılış psikolojisini karşılayacaktır.

\section{2 İktidar, Eylem ve Özneye Dair}

Aktörün varlığı, eylemin varlığı demektir. Eylemin olduğu yerde aktör, aktörün olduğu yerde eylem vardır. Bu anlamda özne ve eylemin bir arada iken bir cümle hâlini aldığını söylemek gerekecektir. $\mathrm{Bu}$ açıdan düşünüldüğünde, aktif katılımı temsil eden özne, katılımı mümkün kılan eylem ve katılım üzerinde belirleyici olan iktidar, tüketim kültürünün aurasını anlama noktasında bize ipucu verecektir. Tüketimin anlamına -eylemleri etkileme derecesine, özneye sirayet etme biçimine, etkileyenin tahakküm biçimine- bu aura ile yaklaşmak, başlığın gidişatını belirlemek için yeterli olacaktır. Tüketim kültürünün aurasının anlaşılması, neoliberal özne, neoliberal öznenin eylemi ve neoliberal öznenin eyleminde belirleyici olan iktidarın anlaşılması etrafında tartışılacaktır. Fakat burada maksat, neoliberalizmin uzun uzadıya açıklanması değil, tek tek özne, eylem ve iktidardaki neoliberal etkinin açıklık kazanmasıdır.

Foucault özne, eylem ve tecrübeyi tanımlarken kurduğu sorunsallaştırmada, herhangi bir şeyi doğru ve yanlış oyununa sokan, onu düşünce nesnesi olarak kuran söylemsel ile söylemsel olmayan pratikler üzerinde durmaktadır. Burada bizim için elzem olan "düşünce" bireyin özne olarak ortaya çıktğı tüm konuşma, yapma ya da davranış biçimlerinde aranması gereken bir şeydir. Diğer yandan bu sorunsallaştırmanın, birilerinin kafasından çıkmadığını ifade etmek gerekir. Örneğin delilik söz konusu olduğunda, birtakım söylemleri, hakikat oyunlarını, tanımları bilmek; bu yolla sorunsallaştırılan şey delilik, kurulmuş olanın akıl hastalığı olarak ortaya çıkmaktadır (Foucault,2019: 12-13). Dolayısıyla bu alan belirli normlar ve kurallar içeren bir iktidar alanı, bu 
alana yönelik bir özne tecrübesi șeklinde kendisini göstermektedir. Bu bağlamda Foucault'un iktidarı; "hayır diyen bir gücün” ötesinde, bedenlere nüfuz eden, şeyler üreten, haz oluşturan, bilgiyi ortaya çıaran, söylem üreten üretken bir ağdır. Bu ağı Han'ın ifadeleri ile düşündüğümüzde, akıl yoluyla etki eden, dışsaldan ziyade içsel bir ağ karşımıza çıkmaktadır. Bu ağ, herhangi bir dış baskıya gereksinim duymadan, kamuoyunun ufkunda normalleştirici bir etki uyandırarak etkisini geliştirmektedir. Böylesi bir iktidar, doğal olanla, söylenmeye gerek kalmadan tamamen kaynaşmış olan, kendi görünmezliğinde parlayan bir iktidardır (Han, 2020a: 38-68). Özne ve eylemin tüketim karşısındaki duruşu, kendi görünmezliğini öznenin rızasına tabi kılan bir varlık kazanarak süreklilik elde edecektir. Burada, birey ve benliğin özne karşısındaki konumu önem arz edecektir.

Söz konusu bağlamda, biz'de bir ben ortaya çıkararak birçok gerçekliğe bölünen bireycilik kırılgan, değişken, bütün reklam ve propagandalara, kitle kültürünün imgelerine bağımlı bir bireyi temsil edecektir. Bu birey, bir süre sonra yeni iletişim sanayilerince üretilmiş arzu ve gereksinimlerin yansıtıldığı bir ekrandan başka bir anlam ifade etmeyecektir. Buradaki özne, benlik kavramının aynı anda hem olup hem olmadığı bir öznedir. Böylesi bir özne; bir durumdan diğerine bir uyarandan diğerine geçip duran, bütünden kopuk, bölünen ve baştan çıkarılan bir özne olarak da karşımıza çlkar. Bu hâliyle özne, bireyin durumlarının, tepki, duygu ve düşüncelerinin oluşturduğu bir hengâmenin içinde kaybolmaktadır. Esasında Touraine, özneyi, kendi kendine bir geri başvuru, sıradan yaşamın akıntısına karşı bir kendine tekrar yönelme istenci olarak aktarmaktadır (Touraine, 2017: 145-146). Bu hâliyle, özlük arayışına yönelen, bir şeyleri özleștiren bir öznenin bizim sorgulamamıza karşılık vereceğini söylemek mümkün olacaktır. Dolayısıyla, özlük arayışını, iletişim sanayilerince üretilmiş arzulara yönelik bir ekrana yönelten özne, bu ekrana bağımlı bir eylem alanı gerçekleștirecek, bu eylemlerin iktidar alanını bu bağlamda inşa edecektir. Neoliberal sürece eylem ve iktidar ilişkisi ile dâhil olan birey, kendi maddi ve manevi değerlerini de bu ilişkiler bağlamında canlandıracaktır.

\section{Aktörler: “En Kral Adam Kendisinin Kralıdır.,*}

Öznenin eylem ve iktidar ilişkisi bağlamındaki varlığının anlaşılmasında, bizim oluşturmaya çalıştığımız tiplemede belirleyici olan "neoliberal varlık" önem kazanacaktır. Nitekim tüketim olgusunun gözetiminde duran, tüketim olgusunu gözeten, tüketim olgusunu belirleyen ve bu olgu tarafından belirlenen, tüketimin hem yöneteni hem yönetileni olan özne, bu yönüyle kendisinin kralı olmaktadır. Byung-Chul Han'ın neoliberal öznede ifade ettiği durum da böylesi bir hâli temsil etmektedir.

Kendisinin kralı olan adamı, gezinen ve girişimci özne bağlamında düşündügümüzde, neoliberal varlık açıklık kazanacaktır. Genel bir tanımlama ile "serbest piyasa ekonomisine" karşılık gelen liberalizm, söz konusu öznenin anlaşılması için bize bir ipucu verecektir. Serbestliğe vurgu yaptığımız bir liberalizm üzerinden gidecek olursak, toplumsal bağ ve zorunluluklarından kurtulmuş, doğal hakları mutlaklaştırılmış, birey odaklı özgür bireyle karşılaşırız (Geçgin ve Ünsaldı, 2013: 72). Bireyin toplumsal varlığının aktif bir güç hâlini aldığı neoliberal mantıkta da, birey pazarların aktörü olurken, adeta bir şirket gibi yönetilmektedir. Dolayısıyla birey, bir yandan kendisine odaklı bir özgür birey olurken diğer yandan da kendisine yönelik özgürlüğü dışarıdaki gücün yönetimi ile oluşturan bir aktör hâline gelmektedir. Buradaki özgür ruh, tuhaf basitlikler ve sahtelikler içinde yaşayan insana ait bir ruhtur. Tuhaf basitlikler ve sahtelikler içinde bulunan insan, istemese de yanlışı severken yapay, düzmece bir dünyanın aktörü olarak buraya anlam atfetmektedir (Nietzsche, 2018: 41).

Maddi değere hizmet eden, maddi değerlerin belirleyici olduğu basitlikler ve sahtelikler içinde yaşam süren birey, en garip nesneleri tüketerek nesnenin al-benisine hizmet etmektedir (Dellaloğlu, 2019: 30-31). Burada isminden söz edilen gezinen ve girişimci öznenin handikapı, içinde bulunduğu fetişizmin farkında olmaması, farkında olsa dahi bu farkındalığa kaydadeğer bir anlam atfetmemesidir. Serbest dolaşım şeklinde nitelendirebileceğimiz neoliberalizmin özgürlüğünün sömürmeye yarayan zekice bir sistem olduğunu vurgulayan Han, bu sistemde yer bulan öznenin başkalarıyla amaçtan yoksun ilişkilere girmekten aciz olduğunu ifade etmektedir. Hassaten bu özne, bir yandan amaçtan yoksunluğu temsil ederken, diğer yandan da özgür bireylerin eylemlerine hizmet edeceği için belirli bir amaçla var olacaktır. Bu anlamda girişimci özne, bir diğer girişimci ile arasında

${ }^{*}$ Platon'dan aktaran; Foucault, ayrıntılı bilgi için bkz: (Han, 2020a: 103) 
kurduğu dostluk ilişkisini belirli bir amaca yönelttiği ölçüde varlığını sürdürecektir (Han, 2019: 12). Bu bağlamda, öznenin varlığına yüklediği anlamı itaat ve rıza etrafında düşünmemiz gerekecektir. İnsan bedeninin onu keşfeden, parçalayan, yeniden düzenleyen bir iktidar makinesinden geçerek birinin arzularına hizmet ettiği (Foucault'tan aktaran; Hallaq, 2020: 178) mantığı, söz konusu ilişkide, yöneltilen amaçsızlığın amaçlılığını gösterecektir. İktidara yönelik bu söylemde öznenin kendi arzuları birilerinin arzuları ile birleşecek, böylelikle gezinen ve girişimci öznenin -gönüllü bir itaat ve rıza ile- eylemsel zeminde sürdürülebilirliği sağlanabilecektir. Gönüllü ilişkiler üzerinden inşa edilen öznenin özgürlüğü, kopuşlarla süreklilik kazanan bir bağlllık şeklinde kendisini göstermektedir.

Kopuşlarla süreklilik kazanan girişimci zihniyetin özgürlüğünün aksine özgürlük, fri kökeninden gelen anlamı ile "sevmek" anlamına gelmektedir. Temelinde sevgi ve bir aradalık barındıran özgürlük; sevgi ve arkadaşlık ilişkilerinde kendini özgür hisseden, ilişkileri ile arasında bağ kuran özne ile tanımlandığında varlık kazanmaktadır (Han, 2018: 42). Girișimci zihniyetle inşa edilmiş bir özne hayaliyle varlık kazanan neoliberal zihniyet böylelikle daha görünür bir hâl almaktadır. Dolayısıyla neoliberal öznenin var ediliş gayesini anlama, bâhusus bir özgürlük sömürüsünden bahsedilmesini zorunlu hâle getirmektedir.

Özgürlük sömürüsü, temelde yoksunlukların özgürlüğü olarak düşünülmelidir. Girişimcilik zihniyetine karşıllk gelebilecek bu özgürlük, bireysel girişimlerin daha etkili olduğu, ekonomik özneler arasındaki özgür yarışmacılığın kurala bağlandığı bir güce bağlanmaktadır. Bu bağlamda girişim özgürlüğü bir çalışma ya da aç kalma özgürlügü, nüfusun büyük bir kısmı için zahmet, güvensizlik ve korkuyu anlatan bir özgürlüktür. Böylesi bir özgürlük, ekonomik, politik ve entelektüel özgürlüklerin geleneksel terimleriyle sınırlandırıldığında tanımlama yerini bulamamaktadır. $\mathrm{Bu}$ yüzden toplumun yeni yeteneklerine karşılık gelen yeni tanımlamalara gereksinim duyulmaktadır. Bu tanımlamanın içerisinde, ekonomik güçler ve ilişkiler tarafından denetlenmekten özgürlük, varoluş için gündelik mücadeleden, geçimini kazanmaktan özgürlük gibi olgular bulunmalıdır (Marcuse, 2010: 19-21). Söz konusu nitelikleri, Han'ın Şiddetin Topolojisi'nde kurgulamış olduğu başarıya ve performansa odaklı geç modern özne karşılamaktadır. Karşısında ne bir düşman, ne de bir hükmeden olan bu özne, kendisini daha fazla iş başarmaya zorlayan bir diş mercii ile değil, kendi rızası ve yönetimi ile kontrol etmektedir. Han’a göre bu özne, ötekine karşı olan düşmanlığını ortadan kaldırmış bir öznedir. Ötekiyle arasında kurduğu ilişkinin farklılık üzerinden içselleştirilmesi, onun kendisini ötekinden özgürleștirmesini sağlamaktadır. Bu durum özne üzerinde patolojik bir kendine yönelmeye yol açmaktadır. Dışarıyla, nesnelerle ve dünyayla bağını gitgide koparan geç modern özne, adeta kendisine rastladığı bir projeksiyon sahası hizmeti görmektedir (Han, 2016: 54-55). Bu projeksiyon sahası, varlı evrenini, ben'lerin gittikçe yaygınlaştığı bir sessiz yığınla geniş̧letmektedir.

Baudrillard, Sessiz Yığınların Gölgesinde'de bu sessiz yığını vurdumduymazlık eylemiyle açıklamaktadır. Bu anlayışa göre ben'lerle kuşatılmış bir yığına vurdumduymazlık hakkı ben'ler tarafından verilmemiştir. Bu hak onlara iktidar tarafından bahşedilmiştir. Bu hakka karşıllık Baudrillard, "bir yığın devrimden, birkaç asırlık politik deneyimden, gazetelerin, sendikaların, partilerin, aydınların halkı harekete geçirmek ve eğitmek için harcadığı tüm çabalardan sonra nasıl olur da gösteri yapan birkaç yüz kişiye karşılık tam yirmi milyon insan edilgin kalır?" sorusunu sormanın gerekli olduğunu vurgulamaktadır. Nitekim sorunun cevabına yönelik tüm çözümlemeler kontrol eden elin güdümlemeyi bütün gücüyle elinde tuttuğunu, bir yandan da anlaşllmaz bir şekilde komaya girmiş bitkin bir kitlenin genişlediğini göstermektedir. Fakat bu genişlemeyi olanaklı kılan edilgin halk, gerçekte ne yolunu şaşırmış ne de gülünç bir duruma düşmüştür. Esasında halk, kontrol eden elin anlamı güdümünde tutma çabasına karşı bir tepki olarak görünür olanın kıymetli olduğu bir anlamsızlığı seçmektedir (Baudrillard, 2013: 19-21). Giddens söz konusu vurdumduymazlığı, yığınların bilimsel açıklamalara karşı yaklaşımları üzerinden açıklamaktadır. Bu anlayışa göre kitle, kararsız, karmakarışık açıklama ve tavırları bildiği hâlde tepki vermemektedir. Kendisi için neyin faydalı neyin zararlı olduğunu kestiremeyen geç modern özne, bir tüketici olarak biftek yemeli mi yememeli mi, bilim adamlarının önemle üzerinde durduğu küresel ısınmaya tepki vermeli mi vermemeli mi bilmemektedir. Bu bağlamda özne, yaşamış olduğu dramatik değişmelerin içinde kendisinin bile anlamadığı bir sistemle boğuşmaktadır (Giddens ve Pierson, 2001: 218-220).

Baudrillard ve Giddens'in yaklaşımlarını ayıran nokta özneye yüklenen eylemle ilgilidir. Giddens, bilmeyen bir özneden bahsetmektedir. Bilmeyen öznenin oluşturduğu bir sessiz yığının ve bildiği 
hâlde bilmeyen öznenin oluşturduğu bir sessiz yığının kontrol eden ele karşı izlediği politika aynı değildir. Nitekim bildiği hâlde bilmeyen sessiz yığınların vurdumduymazlığı, derin düşünme yetisini gönüllü bir anlam belirsizliği üzerinden kurgularken bilmeyen sessiz yığınlar derin düşünme yetisini bilinmeyenin verdiği bir anlam kaybı üzerinden kurgulamaktadır. Neoliberal öznenin içinde bulunduğu durumda iktidar, kontrol etme yetkisini bireylere devrederek verimliliğini artırmaktadır. Dolayısıyla bütün sınıfları içine alan bir şekilde yabancı bir gücün sömürüsünü kendini sömürmeye dönüştüren neoliberal sistemin öznesi, bulunduğu durumda, sistemi sorguya çekmek yerine kendi başarısızlığını sorguya çekmektedir. Bu bağlamda neoliberal özne olaylara karşı tutumunu ve öfkesini daha ziyade kendisine yöneltmiştir (Han, 2019: 16). Başarısızlık durumunda özne, yaşadıkları ve yaşayacaklarının farkında olurken, bu farkındalıkla birlikte içsel bir bunalıma girmektedir. Bu bunalım içerisinde özne, performansına yönelik artan imkânları ile avunarak mevcut olumsuzlukları da geçiștirdiğini düşünmektedir.

Bauman, sessiz yığınlara dönüşen öznenin yaşadığı veya yaşayacağı olayları Orwell ve Huxley'in eserleri ile açıklamaktadır. Bu bağlamda Orwell'in 1984 romanında tasvir ettiği dünya, sefalet ve yoksulluk, kıtlı ve yokluk dünyası, Huxley'in Cesur Yeni Dünya'sı ise refah, zenginlik, bolluk ve bereket dünyasıdır. Bu iki eseri birleştiren unsur, özgürlüğün neredeyse tamamıyla yok edilmekle kalmayıp sadece komutlara uymak ve rutinlerden çıkmamak üzere eğitilmiş insanlar tarafından adeta lanetlendiği, iplerin küçük bir seçkinler grubunun eline verildiği, geri kalanların ise bir kukla gibi yaşadığı, dünyanın yöneten ve yönetilenler, düzen kuranlar ve düzene uyanlar şeklinde iki gruba ayrıldığı, sıkı sıkıya kontrol edilen dünya öngörüleri ile kuşatıldığı bir dünyanın özgürlüğü olarak tanımlanmasıdır. Burada bizim için önemli olan unsur, iki yazarın da kimsenin kendi hayatı üzerinde söz sahibi olmadı̆̆ı bir gelecek tasavvurudur (Bauman, 2018a: 92).

İnsanların mutluluğunun soma denilen bir hapla yönetildiği varsayımıyla kurgulanan Cesur Yeni Dünya'nın sunuş metninde, hiçbir yan etkisi olmaksızın anında mutluluk veren bir dürtüden söz edilmektedir. Bu anlamda bu dünyanın ne tür bir mutluluk vaadinde bulunduğu ve bu mutluluğa karşıllk özneden nasıl bir bedel istediği sorusu önem kazanmaktadır. Bu soruya verilebilecek cevap, ancak her şeyin yüzeysel ve derinlikten yoksun olduğu bir hayal dünyasıdır. Nitekim yüzeysel ve derinlikten yoksun anlamlar, özneye vaadedilen imkânlar ile özneden beklenen bedelleri belirlemektedir. Böylesi bir dünyada, her şey ulaşllabilir olduğu için anlamını yitirmiştir (Huxley, 2013: 7-14). Dolayısıyla Huxley'in dünyası, Orwell'in kıtlık ve imkânsızlık dünyasının aksine sınırsız imkânlarla kuşatılmış bir geleceğin özne üzerinde oluşturduğu kıtlıktır. Neoliberal öznenin ontolojik yapısını da söz konusu imkânlarla kuşatılmış bir gelecekle birlikte düşünmek bu makale için gereklidir. Nitekim karşısına çıkan imkânlar sayesinde adeta yerinde duramayan, sürekli bir turlama eylemi ile daima hareket hâlinde olan, ailesiyle AVM'de hoş bir vakit geçiren, yeri geldiğinde kırsal gezilere çıkarak kısa süreli nostaljiler yapan, şöyle bir dinlenirken kumandasıyla zap yapan, cep telefonuyla sosyal medyayı tavaf eden, kısaca tüketebilecek her şeyi sonuna kadar tüketen özne, eylediklerinin kontrolünü gezintiye teslim etmektedir.

Bauman, Akısskan Modernite'de sonuna kadar tüketen öznenin eylediklerini Anlatma bana, göster, Bağımlılığa dönüșen tutku, tüketicinin bedeni, Bir arınma ayini olarak alışveriș, Satın alma özgürlügü, Birlikteyken ayaktaydık, bölündük alışverişteyiz başlıklarıyla vurgulamaktadır. Başlık vurgusundan önce, gezinen öznenin eylemlerini büyüsü bozulmuş dünya ile açıklamak yerinde olacaktır. Burada tükettikçe daha fazla tüketmek isteyen öznenin, bu tüketimi ihtiyaç duyma hâli ile gerçekleştirdiği üzerinde durulmaktadır. Tüketim için gerekli olan nesnenin elde edilmesi, belirli ortamlarda bulunmayı zorunlu hâle getirmektedir. Bu bağlamda inşa edilen ortamlar, kendi işini kendisi gören üretici tüketicilerł aracılığıyla sürekli hâle gelmektedir (Ritzer, 2016: 21-78). Dolayısıyla tüketen öznenin varlığı, mevcut şartlarda gereksinim duyan değil, gereksinim duyulan bir özne olarak karşımıza çıkmaktadır. Delaloğlu, bu vurguyu vitrini kışkırtan nesneler aracılı̆̆ıyla açıklamaktadır. Bu kışkırtma Pasajların ortaya çıkışıyla birlikte mimaride yer kaplayan demir ve cam aracılığıyla sağlanmıştır. Bu kışkırtma ile özne, artık gereksinim duymadığı zamanlarda da tüketmeye başlamıştır. Metanın kaderini değiştiren estetiğin nesneleşmesi, güzelin ekonomik ve politik bir

\footnotetext{
† Ritzer, üretici tüketicilerin yükselișini eskiden satın alınacak nesneleri bize sunan dükkânlar, süper marketler, fast food restoranları vs. üzerinden açıklamaktadır. Bu bağlamda artık bireye zaman kaybettiren market reyonları, bireyin kendi işini kendi yaptığı fast food restoranları özne eylemlerini şekillendirmektedir (Ritzer, 2016: 78). Bu durum, öznenin sanal ortamdaki eylemlerini anlama noktasında ipucu vereceği için de önem arz edecektir.
} 
kategori hâline gelmesine sebebiyet vermiştir. Dolayısıyla pasajlar gezinen özneyi tahrik ederken, gezinen özne de vitrinleri tahrik etmiştir. Vitrin sayesinde nesneye teslim olan özne, nesnelerin albenisine kapılarak seçimlerini gerçekleştirmeye başlamıştır. Böylelikle nesne özneyi istimlak etmiştir. İstimlak olan özne artık, seçmekten başka seçeneği olmayan, aynı zamanda seçilen bir nesnedir (Dellaloğlu, 2019: 28-29). Bu bağlamda istimlak olan özne gözün etkinliğini kulağın etkinliğinden daha çok önemseyen öznedir (Benjamin, 2007: 132).

Gözün etkinliğinin öznesi, duyduklarından ziyade gördüklerine iştirak etmektedir. Bu bağlamda Bauman‡, TV kanallarındaki sohbet programlarını örnek vermektedir. Tüketici dostu kapitalizmin öznesi, esasında bir ben așkı taşıyan öznedir. Trajik mahrem hikâyeleri kamuya sunan programlar, özneye bu aşkı adeta hatırlatmaktadır. Hayatını en iyi şekilde nasıl yaşayacağının bilgisine yalnızca kendisi hâkim olan özne, bu programlar vasıtasıyla mucizevi çözümlere ulaşmakta, göremediği bir ayrıntıya tanıklık etmektedir. Burada önemli olan, programın öznesinin en özel ayrıntılarına kadar kamusallaşması, programın izleyicisinin ise, bu ayrıntıları sahiplenerek tüketmesidir. Burada özne için bâhusus vurgulanan çözüm, bireylerin kendi yargıları ve kişisel çabalarında yatmaktadır.

Bireyin yargı ve kişisel çabalarını bağımlılığa dönüştüren tutku, onun daima tüketici dostu olmasını sağlayacak bir ilaçtır. Bu ilaç, bireyin sürekli koşturan bir yarışmacı olarak kalmasını sağlamaktadır. Bu yarıșta yarışmacıyı bitiş çizgisine ulaştıracak herhangi bir amaç yoktur. Her bireyin fiilen dâhil olduğu bu yarış arketipi, tipik bir satın alma faaliyetidir. Satın alma faaliyeti, yalnızca fiyat etiketleriyle gerçekleştirilen bir faaliyet olmayıp, sergilenen her türlü mekânı ve eylemi içerisinde barındırmaktadır. Bireyin müstakbel işverenine kendini kabul ettirme çabası, başkalarını olduğu gibi göründüğüne ikna etmek için yapılan giyim ve aksesuar alışverişleri, dikkat çekme ama fazla dikkatli gözlerden de uzak kalma yolu olarak aşktan maksimum tat alma ve bağlanmaktan kaçınma yöntemi vs. bu satın alma eyleminin bir şekilde birer parçası hâline gelmektedir. Diğer yandan tüketicinin bedeni üzerinden tanımlanan "fit" olma, yaşamının her alanı "fit" olan bir tüketim vasıtası olarak düșünülmektedir. Fit olma noktasında sınırları zorlayan tüketici özne, bir kez olsun kendinden emin olma, kendine güvenme ve güvenilir olma isteğine bağlı olarak alışverişi her gün yaptığı gündüz ayinlerine dönüştürmektedir. Bu bağlamda özne, kendisini bir satın alma özgürlüğünün içerisinde hissetmektedir\$.

Satın alma özgürlüğü, insanların zorlama ve baskıyla değil ikna ve baştan çıkarma yoluyla standartlaştırıldığı bir özgürlüktür. Bu anlamda satın alma özgürlüğüne bağlı gerçekleștirilen seçimde lütuf ve lanet bir aradadır. Önemli olan neyin seçildiği değil seçme eyleminin kendisidir. Bu eylem, seçimi yapan kişiye tahsis edilmiş kaynakların hacminin bir fonksiyonudur. Bu eylemin sahipleri, arzu ettiklerine kolayca ulaşabildikleri kadar istemediklerini kolayca elden çıkarma hakkına da sahiptir.** Girişimciliğin özne üzerinde oluşturmuş olduğu politik boyutun bir sonucu olarak ortaya çıkan gezinen özne, böylelikle tüketen, başarısı ve performansı için kendine odaklanan, kendine odaklandığı için, benliğini tutkulu bir tüketime teslim eden psikopolitik bir insana dönüşmektedir.

\footnotetext{
‡ Bu değerlendirme Bauman'ın Akışkan Modernite adlı kitabının söz konusu başlıklarından derlenerek oluşturulmuştur. Ayrıntılı bilgi için bkz: (Bauman, 2018a: 105-141).

$\S$ Bir önceki dipnotun devamıdır.

** Bir önceki dipnotun devamıdır.
} 
"Gezgin, kimsin sen? Görüyorum, yürüyorsun yolunda dudaklarında alaylı gülümsemen olmadan, sevgisiz, dipsiz gözlerinle; nemli ve acılı bir derinlik ölçer aygıtı gibi, doymamış, derinlerden gün ışığına her çıkışında -ne arıyorsun aşağılarda?-İ geçirmeyen bir göğüs, nefretini saklayan bir dudakla, bir elle, yalnızca yavaş yavaş yakalayabilen: Kimsin sen? Ne yapıyorsun?..."

\section{Nietzsche ${ }^{\dagger \dagger}$}

Tüketim, evvela maddi değeri olan nesnelerin teminine yönelik bir kavram olarak öne çıkmaktadır. Fakat ele alınan çalışmadaki anlamı ile tüketim, yalnızca söz konusu hâl üzere olmamakla birlikte, aynı zamanda yaşamı pek çok yönüyle temsil eden, öznenin çeşitli anlamlara haiz kıldığı eylemleri de bu sürece dâhil eden bir kavram olarak karşımıza çıkmaktadır. Bu bağlamda, tüketim olgusu ve tüketim aktörünün; hayatını gündelik yaşamın ortak tüketim araçlarına bağlayan öznenin imkânları ve bu imkânların psikopolitikasının insan varlığına sirayeti şeklinde düşünülmesi mezkûr tipleştirmenin özelliklerinin temsilinde önemli bir yerde duracaktır.

Neoliberal varlık üzerinden şekillenen eylemleri temsil eden bu öznenin, belirsizlikten beslenen, belirsizliği arzulayan, kendine yönelik tanımlayıcı net ifadeleri belirsizlik çerçevesinde kurgulayan, herhangi bir eylemin hem kendisini hem de kendisi olmayanı isteyen absürt bir tiplemeyi karşılaması, budala derken neyi kastettiğimizi göstermektedir. Bu anlamda aktörleri temsil eden başlıkta ele alınan gezinen, girişimci başarı ve performans öznesi bizim için önem arz edecektir. Bu bağlamda, yeni budalanın çıkış noktasına yöneltilecek soru; "gezgin, kimsin sen?” sorusu olacaktır.

Söz konusu soruya açıklık getirmemize olanak sunacak ilk cevap, "kendisi dışındaki bir iktidar kurumunun baskısına maruz kalmadığı sürece özgür olan, öteki yahut bir düșmanın sorumluluğunu üzerinden atarak yalnızca kendine yönelen insan" șeklinde ifade edilmelidir (Han, 2016: 10-11). Bu insanı temsil eden özne, siyasete yalnızca șikâyet ederek tepki gösteren; iştirak etmiş bir katılımcıdan ziyade pasif bir seyirci olan; interneti, doğayı, değerleri tüketerek zamanını harcayan bir öznedir (Han, 2019: 12-21). Burada üzerinde durulması gereken özellikler; yalnızca kendine yönelen insan ve bu yönelimi pasif bir seyirci olarak gerçekleștiren insandır. Özne belirgin bir șekilde kendine mi yönelmektedir ve sahiden yalnızca pasif bir seyirci midir? Nitekim "absürt olanı isteyen" bir öznenin "isteyen" bir iştirakçi olması, onu pasif bir seyirci olmaktan çıkarmakta ve aktif bir katılımcı hâline getirmektedir. Bu bağlamda özne, başına gelenleri kabullenme değil, bașına gelenleri arzulama, bu arzuya yönelik bir tatmin arayışı ile sessiz yığınlara dönüşmektedir. Bu durumda sessiz yığınlar ifadesinin kendisi de bir bakıma anlamını yitirmektedir. Nitekim bu yığınlar, arzu etme ve tatmin arayışına yönelik faaliyetini, vurdumduymazlık üzerinden değil, bir hoşnut olma, memnuniyet duyma hâli ile birlikte gerçekleştirmektedir.

Gezgin, girișimci başarı ve performans öznesinin bu boyutu pürüzsüzlük üzerinden düşünülmelidir. Hayatının neredeyse tamamında yeni budalanın aradığı huzur, pürüzsüz bir huzurdur. Pürüzsüz için dünya; içinde acı, yara, kabahat olmayan, saf pozitiflik dolu bir dünyadır. Bedenden başlayan, hayatın her alanını kuşatan bu dünya, hadiselerin ve yazglların olmadığı bir dünyadır. Bu dünya, boşluk üreten, bir bakışı, örtüsü olmayan bir düzene sahiptir (Han,2020b: 3-32). Pürüzsüzlügü örneklendirme noktasında günlük yaşamda "makyaj” olarak zikredilen cilt boyaları bir ipucu niteliği tașlyacaktır. Yüz özelinde bașlayan bu boyama ișleminde özne, kabahatleri kapamakta, kendisi ve diğerleri tarafından çirkinlik addettiği taraflarını güzelleştirmektedir. Bu hâliyle bireyin dünyasında oluşan boşluk, bir bakıma örtü ile kapatılmaktadır. Böylelikle bireyin pürüzlerine ait hadiseler ortadan kalkmasa da bir süre görünmez olmaktadır. Bu noktada Aydemir tarafından "süslü" olarak nitelendirilen tipleme pürüzsüzlüğü arzulayan öznenin özelliklerini karşllamaktadır. Özel olmanın al-benisine kapılan, fark edilmek ve görünür olmak isteyen bu tipleme bireyselliği talep etmekte, kendisi olarak var olmak ve sahip olduklarını göstermek istemektedir (Aydemir, 2016: 453-454). Burada öznenin yalnızca kendine yönelen insanın ötesine geçtiği anlaşılacaktır. Öznenin huzurunun fark edilme ve buna bağlı bir beğenilme isteğine bağlı olması, kendine yönelmek için başkalarının arzularına yönelen bir tiplemeyi karşımıza çıkarmaktadır. Bu anlamda yeni budalanın arzu ettiği huzur pürüzsüz bir huzur iken, gerçekte olan pürüzsüzmüş gibi görünen bir huzurdur. Pürüzsüzmüş

†+ Epigrafta neşredilen ifade, Nietzsche'ye aittir. Bkz: (2018: 207). 
gibi görünen, bireyin hayatının neredeyse tamamını kaplayan bu durum yaşama çıkar birliği doğrultusunda bağlı olan bir özneye yer açmaktadır. Giriştiği yaşama yalnızca çıkar birliği ile bağlı olan, bu ilişkilere yönelik bir özgürlüğü kontrol altında tutmak için gezinip duran özne, geldiği noktada başkalarının beğeni yargıları üzerine yaşamını şekillendiren, bu yargıları düstur edinen, bu yargılar ile yalnızca kendisi için yaşayan konumuna ulaşan bir "budala" olmaktadır. Bu hâliyle gezgin, girişimci başarı ve performans öznesinin kendisini şekillendirdiği norm, rollerini bir kabullenme ile değil kendine bağlı bir arzulama ile tanımlanmıștır. Önemli olan rolü oynama kabiliyeti ve istekliliktir. Bu bağlamda yaşamdaki düzen tüketilecek unsurların üretimi ile sağlanmaktadır (Bauman, 2014: 92-93). Bu unsurlar zamanla bir nesne olmaktan çlkmakta, bireyin kendisine yönelmektedir. Burada bir eylem olan tüketmek, insanı tüketen bir tüketmek olarak karşımıza çıkmaktadır. Dolayısıyla insanı budalaya dönüştüren güç, kitleleri baskılama ve engelleme yerine onu motive eden, harekete geçiren; yasak ve yoksun bırakmanın ötesinde bir tatmin sağlayan bağımlılık yaratarak söz konusu düzeni rıza ilişkisi çerçevesinde yönetmektedir (Han, 2019: 24). Bu hâliyle yeni budala, kendisine atfedilen bu girişimciliği kendisi tarafından içselleștiren, ona kendisinin kralıymış gibi davranmayı öğreten güce rıza gösteren öznedir.

Öznenin içselleştirilmiş girişimcilik vasfını köstebek-yılan ilişkisi şeklinde düşünürsek, neoliberal kontrolü, toplumun hayvanı olarak görebiliriz. Yılanın hareket alanı, köstebeğin kapalı mekânlarının aksine kullanıma açık olan bir mekândır. Yılan, girişimcidir. Hazır döșenmiş mekânlarda hareket etmez, bir projedir; mekânı kullanıma açar. Köstebeğin sınırları vardır, yılan sınırları aşar. Daha fazla üretkenliğe odaklanan kapitalizm bu yüzden köstebek modelinden yılan modeline geçmektedir (Han, 2019: 28). Daha fazla üretkenliğe odaklanan kapitalizm, tüketim bağımlığına yönelik bir üretim gerçekleștirecektir. Yeni budala ise bu bağımlılığı üretecek madde ve ortamları kendisi kullanıma açacaktır. Kullanım alanlarını açtıkça, tüketimin sınırlarını zorlamak istediğini fark edecek olan da bu öznedir. Bu durum başlangıçta sadece tüketenler için geçerliymiş gibi görünse de aslında tüketemeyenler için de geçerlidir. Tüketemeyenler, tüketenin imkânlarına sahip olmayı hayal eden, hayatının bir noktasında dahi olsa tüketen bir özne olarak tanınmak isteyenlerdir. Bu bağlamda tüketemeyenler, kendisine dayatılan kapalı mekânlardan çıkamayanlar, bir gün açılk ve hareketli mekânlarda varlık sergileyecek olmayı hayal edenlerdir. Bu yüzden tüketemeyenler için de tüketmek, başkasında anormal, eleştiriye açık bir eylemken, kendisinde normal, eleştiriye kapalı bir eylem hâlini almaktadır. Bu bağlamda insanlığın neredeyse tamamının bir süre sonra tüketim mekanizmasına dâhil olan yeni budalalara dönüşeceğini öngörmek, abartı olmayacaktır. Bu hâliyle de yeni budala, "en kral adam" olmayı sahip olduğu tüketme olanaklarını genişleterek sağlayacağını düşünen öznedir.

"En kral adam" olmayı arzulayan gezgin, özgürleștirici bireyciliğin savunucusu kıllğına bürünen bir pazarın erkine boyun eğmeyi dayatan bir tüketici bireyliğin içine dâhildir (Touraine, 2014: 39). Bu erke boyun eğecek imkânları elde edinemediğinde huzursuz olan gezgin, arzu ettikleri ve tatmin olamadıkları noktasında huzursuzluk yaşayan bir performans öznesidir. Onun budala yapan özelliği bu huzursuzluktur. Bu huzursuzluğu gidermesinin yolu, kendisini keşfetmesine yardım edecek başka tüketim araçlarıdır. Bu durumda yeni budala, biraz da kendini keşfedemeyen öznedir. Çok sayıda kendini yönetme atölyeleri, motivasyon artırıcı hafta sonları, yaşam koçları, kişilik geliştirme seminerleri ve zihin antrenmanlarıyla hayatındaki pürüzleri en aza indirgemeye çalışmaktadır. Neoliberal tahakküm teknikleri bu pürüzleri tespit ederek özneyi tatmin edecek araçları yönetme fırsatı edinirken, onun hayatının bizzat yine kendisi aracılığıyla sömürülmesini sağlamaktadır (Han, 2019: 37). Dolayısıyla yeni budala, koşullandırılmış bir pürüzsüzlük endişesini daha pürüzsüz olmanın yolları ile gidermeye çalışan bir özne konumunda bulunmaktadır.

Yeni budalayı yönlendiren, onun "ne arıyorsun aşağılarda?" sorusuna cevap vermesinde belirleyici olan psikopolitik güç de onun pürüzsüzlük arayışını perçinleyecek olumlu uyaranlarla iş görmektedir. Bu güç, özneyi pürüzsüzleștirecek malzemeleri silmek yerine not almaktadır. Budalalaştıran davranışları engellemek yerine tahminler yürütmekte ve ön ayak olmaktadır (Han, 2019: 43). Bu akıllı politika, özneleri benliksiz eylemlerle koşullandırmaktadır. Sürece iştirak edecek olan benliksiz özne de, "eğlenmeyen ama eğleniyor gibi görünen" (Adorno, 2014: 146), bir süre sonra "eğlendiğini zanneden", "eğlenmenin yalnızca eğleniyormuş gibi davranmayı sağlayacak eylemlerle mümkün olacağını düşünen" bir tipleme olarak ortamda bulunmaktadır. Eğlendiğini zannetmek için gerekli olan tüketimin sınırlarının genişliği benliksiz özneler arasında oluşan bir iletişim tüketimine ortam hazırlamaktadır. Hayatı yoğun yaşayan, hayatın niteliği üzerinde tefekkür etmeye, durup 
düşünmeye vakti olmayan, bir anlığına da olsa durmayı yarıştan kopmak olarak düşünen aktif olma çabasındaki öznenin mutluluğu sürekli olarak tüketmeye (İnce, 2020: 153-154) bağlı olduğu gibi, iletişimi de bu sürekli olarak tüketmeye bağlıdır. Böylelikle trafikte yeşil ışığın yanmasını bekleyen şoför, karşı caddeye geçmeye çalışan yaya, mağazada sıra bekleyen müşteri, durakta otobüs bekleyen yolcu, bir akșam vakti çay keyfi yapmak üzere bir araya gelen ailenin fertleri, iş yerinde mola vakti gelen çalışan, gece uykusuna geçmeden önce telefonuna gelen bildirimleri kontrol eden genç vs. akıştan arta kalan vakitlerini akıllı telefonlara teslim etmektedir. Daha fazla kitleye ve daha fazla etkinliğe hitap eden sanal ortamlar bu tüketimi mümkün kılmaktadır. Özne buradaki hâli ile kendine çekilerek çevresindekilerden soyutlanırken pürüzleri en aza indirgeyen akışta aktif kalmaya devam etmektedir.

\section{1 “Absürt” Olanın Dijital Görünürlüğü: Sanal Odalar}

Görünürlüğün egemen olduğu bir tüketim faaliyetinin içerisinde, sınırları zorlayarak kendisini tüketmeye adım atan özne, dijital mekânlara eğilim gösterecektir. Tüketimin doruk noktası olarak nitelendirebileceğimiz bu durum, başından beri ifade etmeye çalıștığımız olumluluk sürecinin bir parçasıdır. Bu olumluluk sürecinde, tüketimle birlikte aklımıza gelen ihtiyaç, bolluk ve aşırılık öznenin eylemlerini anlamamızı sağlayacaktır.

Söz konusu anlamı yakalayabilmek adına, yönelteceğimiz soru ise; "ne yapıyorsun?" sorusu olacaktır. Birey neye ihtiyaç duymaktadır? Neyin bolluğunu talep etmektedir? Bu ihtiyaç ve bolluk talebi doğrultusunda ne yapmaktadır? Bu sorular üzerine odaklanmak, dijital bireyi özneleştiren hâller üzerinde belirleyicidir. Bu noktada, birey evvela pasajlarda başlayan tüketim sürecinin görünürlük mekânlarında devam etmesini istemektedir. Byung-Chul Han bu süreçteki aktif katılımcının artık bolluğu değil aşırılığı talep ettiğini ifade etmektedir. Burada esas olan unsur, gönüllü kendini sergilemedir. İnsanları akıllı telefonlara kapatan bu sergi, gözetimin daha verimli kılındığı sanal odalarda gerçekleşmektedir (Han, 2019: 46). Görünürlük mekânlarında, kendisini ve kendisi ile ilgili olanları sergileyerek bolluğa ulaşmaya çalışan özne, sergi değerini ortaya koydukça aşırı olanı talep ederek yeni budalalaşmaktadır. Buradaki aşırılık "absürt olanı" temsil eden bir eylem iken, bu absürtlüğü gönüllü olarak talep eden özne ise, "yeni budala" olarak karşımıza çıkmaktadır. Herkesin birbirini gözetlemesine ve birbiri tarafından gözetlenmesine imkân sunan sanal odalar ise söz konusu verimliliğin gönüllü bir şekilde gerçekleștiği absürt mekânlar olarak düşünülmektedir.

Mekânın absürt olarak nitelenmesinin sebebi, bireyin normallerinde gözlemlenen değişikliklerden ileri gelmektedir. Bu mekânlara bir kullanıcı hesabı oluşturarak erişim sağlayan birey, kendisi için inşa ettiği sanal odanın görünmezliğine dayanarak bir görünürlük alanı oluşturmaktadır. Hesabını hem gizleyerek özelleştirme, hem de gizliliği kaldırarak kamusallaştırma hakkına sahip olan bu birey, her koşul ve şartta kendisini birilerinin gözetimine tâbi kılmak için bir sergileme alanı oluşturmaktadır. Böylelikle gezinen, girişimci başarı ve performans öznesi, insansız kitlelerin onu takip etmesini sağlamakta, nerede, neyi, ne kadar tükettiğinden haberdar olmaktadır. Ayrıca sergileme eylemini gerçekleştiren özne, diğerlerinin ötesinde kendisinin ötesine geçmek istemekte, yaptığı her paylaşımda hem başkalarını hem kendisini aşmış olmaktadır. Öznenin ulaşmak istediği nihai nokta böylelikle yerini bir ulaşmama, ulaşma gibi bir tatmin arayışında bulunmama hâline bırakmaktadır. Bu durumda hem kendisini hem başkalarını aştıkça kendisine yeni bir hedef belirleyen özne diğerlerinin görüşlerini bir dayanak noktası olarak kabul etmektedir. Sonuç olarak ulaşllacak hedefler, hedefleri belirleyen fikirler, faaliyete geçirilen eylemler, hedeflere, fikirlere ve eylemlere verilen tepkiler gerçeği temsil eden gerçek dışı bir hâl almaktadır. Gerçeği temsil eden hedeflere, fikirlere ve eylemlere süreklilik kazandıran, herkesin birbirini tanıdığı, ama hiç kimsenin birbirini anlamak için çaba göstermeye lüzum görmediği soyut mekân insanların hayatında vazgeçilmez bir yer edinmektedir.

Bu soyut mekânda, birbirini anlama gayreti taşımayan insanlar, her şeyden şüphe duymayı bırakarak pürüzsüzlüğe odaklanmaktadır. Bu anlamda, özneyi yeni budala olarak tanımlamamıza sebebiyet veren özellik, onun "filtreleme" özelliğinden kaynaklanmaktadır. Yeni budala, bir yandan kendisinden çıkacak apaçıklıkların peşinden koşarken bir yandan da kendisini ele verecek apaçıklıkları filtreleyerek yaşamının pürüzlü yanlarını kapatmaktadır. Bu filtrelemede yeni budalayı ele veren unsur, onun ideal insan ve ideal yaşam tasavvurunda hangi özelliklerin haiz olduğu; onun nelerden hoşlanmak istediği, hangi mekânlarda takılmak için özel bir çaba harcadığı, hangi hayatın öznesi olmak istediği konusunda takipçisine şifreler vermesidir. Burada da yeni budala, "şeyleri 
doğrudan göstermek yerine ima eden" (Han, 2020b: 139) bir tipleme olarak karşımıza çıkmaktadır. Bu tipleme için "ideal" kavramından sonra önemli olan kavram "ulaşma" kavramıdır. Bir "ideal" belirleme noktasında filtrelemeyi kullanan özne, kendisi için "ulaşılmaz" olan bir şeyi sergilediğini düşünmekte, diğerlerinin de bu "ulaşılmazlığı" beğenmesini istemektedir. İnsanın "ulașılmaz" olana duyduğu ilgiyi sanal odalar üzerinden düşünecek olursak pürüzsüzlüğün neden olumluluğa karşıllık geldiği anlaşılacaktır. Bu anlamda insanın kovaladığı, ima ettiği, çekici ve olumlu bulduğu pürüzsüzlük onun ulaşılmazlığında gizlidir.

Bir arzu ve tatmin mefhumu olarak bireyin yaşamında yer bulan dijital ortamın söz konusu özneyi yansıtan bir başka özelliği, bu ortamlar vasıtasıyla inşa edilen sanal odalarda, bireyin bir duygulanım boşalması yaşamasına imkân sunmasıdır. Duygulanımın kendisinin anlık bir edim olması, onu duygulardan ayıracaktır. Tüketim kapitalizminde var olan edim, duygulanımdır. Sanal odalarda tüketim nesnesi hâlini alan da tüketilenler değil duygulardır (Han, 2019: 50-55). Bireyi anlık duygulanımlara alıştıran bu ortamlarda, duyguların, kalıcı etkisini azaltarak bir tüketilen vazifesi görebilmesi kolaylaşmaktadır. Psikolojik tahakkümün yapmak istediği de budur. Duygulanımın özerkliğinin, kamuya açma ya da daha özel bir alanla sınırlandırma özgürlüğünün sanal odanın sahibinin ellerine bırakılması, duyguların etkisiyle oynayabilme yetisinin tüketimin bir parçası hâline geldiğini göstermektedir. Bu izlekte birey, geçmişin izlerini, artık modası geçmiş utanç verici içerikleri ve dün önemsendiği hâlde bugün önemi kalmamış içerikleri tek çırpıda yok edebilmektedir. Dolayısıyla bu ortamlar, 'sürekli yeniden inşa etme' ihtiyacını kontrol altında tutmaktadır (Bauman, 2018b: 21). Diğer yandan bu yeniden inşa etme süreci, öznenin sömüren, sömürülen, gözetleyen ve gözetlenen olması için gerekli olan kalıcılığı da sağlamaktadır.

Sonuç olarak neoliberal varlık çerçevesinde inşa edilen psikolojik politika, belirli bir programlama ve yönlendirme ile mevcut yapının oluşumuna bir sabite kazandırmaktadır. Yeni budalanın bu sabitelerden şüphe duymak gibi bir derdinin olmaması, bu durumdan duyduğu memnuniyet, söz konusu sistemin başarılı bir tahakküm uyguladığını göstermektedir. Bu hâliyle özne, bir yandan mevcut sistemi yönlendirirken bir yandan da mevcut sistem tarafından yönetilmektedir. Dolayısıyla yeni budalayı temsil eden özne -herhangi bir güç uygulanmaksızın- psikolojik varlıktan arınmış bir öznedir. Arınmış olan bu özne, mevcut seçeneklerin inşasında belirleyici olmakla birlikte bu seçeneklerin kendisi olan; bu yönüyle hem seçen hem de seçilen bir özne olarak absürt bir varlığı temsil etmektedir.

\section{Sonuç}

İnsani eylemleri kontrol altına alan birçok gösterge, sosyolojik alan yazınında oldukça önemli bir yer tutmuştur. Eylemler üzerinde gerçekleşen derin düşünce yetisinin özneyi terk etmesinin insanı nasıl bir yaşama sürüklediği noktasında birçok düşünür kafa yormuştur. Bugün, eylemlerin anlamlarına dair palyatif çözümlemeler sunmaktan öteye henüz gidememiş olan tanımlamalardan birkaçı; risk toplumu, hipergerçek toplum, bilgi toplumu, bilişim toplumu vs. gibi tanımlamalar olmuştur. Bu toplum tanımlamalarındaki iktidar, eylem ve özne ilişkisinin nasıl yansıtıldığı, bu ilişkilerin tüketim olgusu ile kurduğu bağ, makale boyunca zikredilen tiplemenin derin düşünce yetisinin neresinde durduğunun anlaşılmasında önem kazanmıştır. Bu anlamda, insanın vitrinlerden başlayarak bütün etkileşim alanlarına yayılan eylemlerinin zeminini tüketim olgusunun oluşturduğu anlaşılmıştır.

Eylemleri niteleyen kültürel bir gösteren olarak tüketimin özne inşası üzerindeki etkisini yansıtmaya yönelik genel değerlendirmelerin toparlanması, makalede zikredilen tipleştirmenin ayan olmasında belirleyici olmuştur. Bu izlekte, günlük eylemleri düşünsel bir zemine oturtan neoliberal varlık, bu varlığın psikolojik ve politik bağlamı üzerinde durularak, geç modern, girişimci, gezinen, başarı ve performansa odaklı sessiz yığınların özellikleri tespit edilmiştir. Kendini kontrol eden, kendini gözeten, gözetleyen, kendisi üzerindeki iktidar yetkisini kendisi belirleyen, kendini kendisi ile sömüren "en kral adam" tanımlaması yeni budalayı tanımlayan özelliği temsil etmiștir.

"En kral adam" olan geç modern, girişimci, gezinen başarı ve performans öznesi; kurgulamış olduğu ve kendisi için kurgulanan özgürlük toplumunda, yasak ve emirlerle dolu olumsuzluklardan kendini alıkoymuş, tüketim faaliyetinin kendisinde aktörel bir konum sergilemiştir. Bu öznenin niteliklerini taşıyan yeni budala; kendine dalan, karşısına çıkan her şeyde kendini yaşamak isteyen, bir şeyi bitirme niyeti taşımayan, yolda kaybolan, kendini bulma gayreti taşımayan, kendini kaybolmakta bulan, kafası karışan, netliği karışıklık olan, bir başkasının ötesinde kendi gölgesini geçmek için çaba harcayan bir tiplemedir. Sermayenin iktidarı karşısında vurdumduymazlıktan ziyade rızaya dayalı 
bir duruş sergileyen insanlar, yeni budalayı var etmiştir. Tiplemeye dair özellikleri kendisinde toplayan özne, hayatındaki pürüzleri en aza indirgeyerek doluluğa değil aşırılığa talip olan; böylelikle olumluluğun kendisi üzerindeki şiddetini bir özgürlük göstergesi olarak gören bir öznedir. Bu özgürlükle beraber yeni budala, kendi etrafında dönen, sonunda kendisini de tüketen insanları temsil etmiştir.

Son olarak "absürt olanı isteyen" yeni budala tiplemesinin varlığı üzerine konuşulması, insanlığın gittikçe kötüye gittiği, hepimizin kaçınılmaz bir budalalığa doğru sürüklendiği izlenimi oluşturmamalıdır. Nitekim buradaki maksat, "insanlık budaladır!” gibi genel ve peşin hükümlü bir yargıda bulunmak değil, Byung-Chul Han tarafından zikredilmiş olan -toplum tanımlamalarının özneleri üzerinde gözlemleyebileceğimiz- bir tipleştirmenin anlamlandırılmasıdır. Bu anlamlandırmada, belki de çözüm önerisi olarak düşünebileceğimiz bir sonuç; bilinçlilik hâlidir. Bu bilinçlilik hâli -fırsatları kendi değerlerimizle birlikte düşünmemizi sağlayacak bir derin düşünce yetisi, geçmiş, bugün ve yarın arasında kurulan bir anlatı bağı- imkânların verimli kullanımı için önemlidir.

Hakem Değerlendirmesi: Dış bağımsız.

Çıkar Çatışması: Yazar çıkar çatışması bildirmemiştir.

Finansal Destek: Yazar bu çalışma için finansal destek almadığını beyan etmiştir.

Peer-review: Externally peer-reviewed.

Conflict of Interest: The author declare no potential conflicts of interest with respect to the research, authorship, and/or publication of this article.

Grant Support: The author received no financial support for the research, authorship, and/or publication of this article.

\section{Kaynakça/ References}

Adorno, T. (2014). Minima moralia sakatlanmış yaşamdan yansımalar (Çev: O.Koçak ve A.Doğukan) İstanbul: Metis Yayınları.

Aydemir, M. A. (2016). Süslü: Yeni dünyanın tematik insanı, Aydemir, M. A. (Ed.) Toplumsal Tipler içinde. İstanbul: Açılım Kitap.

Bauman, Z. (2014) Küreselleşme toplumsal sonuçları, (Çev: A.Yıldız) İstanbul: Ayrıntı Yayınları.

Bauman, Z. (2018a). Akışkan modernite (Çev: S. O. Çavuş) İstanbul: Can Sanat Yayınları.

Bauman, Z. (2018b). Akışkan modern dünyadan 44 Mektup (Çev: P.Siral) İstanbul: Habitus Yayıncılık.

Baudrillard, J. (2013). Sessiz yığınların gölgesinde toplumsalın sonu, (Çev: O.Adanır) Ankara: DoğuBat Yayınları.

Benjamin, W. (2007). Pasajlar (Çev: A. Cemal) İstanbul: Yapı Kredi Yayınları.

Delaloğlu, B. F. (2019). Zamanın içinden zamanın dışından gelenek ve modernlik arasında, Ankara: Heretik Yayıncilık.

Foucault, M. (2019). Özne ve iktidar, (Çev: I. Ergüden ve O. Akınhay) İstanbul: Ayrıntı Yayınları.

Giddens, A., Pierson, C. (2001). Anthony Giddens'le söyleşiler modernliği anlamlandırmak (Çev: S. Uyurkurak ve M. Sağlam) İstanbul: Alfa Yayınları.

Han, B. C. (2020a). İktidar nedir? (Çev: M. Özdemir) İstanbul: İnsan Yayınları.

Han, B. C. (2020b). Güzeli kurtarmak (Çev: K. Filiz) İstanbul: İnsan Yayınları.

Han, B. C. (2019). Psikopolitika neoliberalizm ve yeni iktidar teknikleri, (Çev: H. Barıșcan) İstanbul: Metis Yayınları. 
Han, B. C. (2018). Zamanın kokusu bulunma sanatı üzerine felsefi bir deneme (Çev: Ş. Öztürk) İstanbul: Metis Yayınları.

Han, B.C. (2016). Şiddetin topolojisi, (Çev: D. Zaptçığlu) İstanbul: Metis Yayınları.

Hallaq, W., B. (2020). Imkânsız devlet, (Çev: A. Hikmet) İstanbul: Babil Kitap.

Huxley, A. (2013). Cesur yeni dünya (Çev: Ü. Tosun) İstanbul: İthaki Yayınları.

İnce, A. (2020). Eğitilmiş insanın imali günümüz eğitim anlayışı üzerine deneme, İstanbul: İnsan Yayınlarl.

Marcuse, H. (2010). Tek boyutlu insan ileri işleyim toplumunun ideolojisi üzerine incelemeler (Çev: A. Yardımlı) İstanbul: İdea Yayınları.

Nietszche, F. (2018). Lyinin ve kötünün ötesinde, (Çev: A. İnam) İstanbul: Say Yayınları.

Ritzer, G. (2016). Büyüsü bozulmuş dünyayı büyülemek, (Çev: F. Payzin). İstanbul: Ayrıntı Yayınları.

Touraine, A. (2017). Bugünün dünyasını anlamak için yeni bir paradigma, (Çev: O. Kunal) İstanbul: Yapı Kredi Yayınları.

Touraine, A. (2014). Toplumların sonu (Çev: O. Kunal) İstanbul: Yapı Kredi Yayınları.

Ünsaldı, L., Geçgin, E. (2013). Sosyoloji tarihi Dünya'da ve Türkiye’de, Ankara: Heretik Yayıncılık. 